\title{
AESTHETICS AND CULTURAL ASPECTS OF BAUHAUS: TOWARDS A NEW CONCEPTION
}

\section{A B S T R A C T}

This article covers the new possibilities of the Bauhaus worldview: the creation of new forms for depicting human ideals through a focus on aesthetics and technology, combined with Niemeyer's impact on architecture and design. New styles and shapes have arisen as offshoots from Bauhaus, conveying the values of each culture through the construction of a collective "picture" world. The Bauhaus of today expresses the culture industry, dialectically considering innovation and applied art as a path from the modern design of the industrial revolution to "eco-design." In this sense, Bauhaus is still significant in its role, linking together art, technology, and industry. Innovation as a dynamic determination of the moment, present in all epochs, is understood as a potent force for maintaining tradition. In addition to a chronological record of the influence of Bauhaus, the significant projects of Niemeyer are discussed. Finally, two perspectives on the "schism" between architecture and technology are presented. The first perspective concerns the human ability to create models in architectural practice for adoption as a configuration of the space. The second relates the evolution of technologies leading to the imagined becoming a reality through time, as described by Hegel (1823).

\author{
Christiane Wagner \\ University of Campinas, Brazil \\ christiane.wagner@malix.univ-paris1.fr
}

KEY WORDS

CUSTOM-MADE

TECHNOLOGICAL DEVELOPMENTS

SPACE-TIME

NEW FORMS 


\section{INTRODUCTION}

Bauhaus is related to aesthetics and architecture in the reflection of artistic creation, the means leading to design in this production area, where artists and artisans are technicians and experts in manufacturing forms with a functional aim. These forms are necessarily useful, thus emphasising its technical aspects.

According to a synthesis by Ursula Meyer, we can consider the technical aspect, from a philosophical perspective, as the medium that allows the human a capacity for imagination and respresentation. Individuals are conditioned to employ pragmatic forms to achieve their goals. So, in this approach, the origin of the term technology should be analysed. This definition would have an original technical meaning in ancient Greece. At the time, the term technè contained, as a whole, a definition broader than that of today. In ancient Greece, it was not only used for machines or the production of objects. The word technè did not differentiate between activities such as those of manual work, creative, art, or military strategies. Thus, the use of the word technè expressed as much meaning for technical actions as for the mental, such as rhetoric, poetry, and arithmetic. Today, the "technical" concept also generates the idea of a procedure of technological knowledge. As a phenomenon, technology is also the subject of philosophy and a subject of study for sociology and applied arts. Additionally, among several definitions of the technical concept, the definition of "technology" in English is known as the science of production and its processes. In Latin, the word technologia included arts education, systems, and methods of Artes Liberales (the seven liberal arts: grammar, astronomy, music, rhetoric, dialectic, arithmetic, and geometry). These were the most important disciplines in Antiquity and the Middle Ages.

Therefore, architecture in the configurations of medieval cities has a central strength in the construction of cathedrals, showing their "liberation" of the mechanical arts. With the cathedra (seat), art represents an extreme promotion of architecture, providing the medieval cities the role of capital, showing itself as a symbol of superiority and authority, not only by the well-calculated harmony of their buildings but also by the height of their vaults. This symbol is not limited to the power exerted by the cathedral, but also to the value, the perfection, and the architectural grandeur, which - since the Italian Renaissance - possess strength in France and throughout other countries, thus representing an aesthetic value through the most beautiful examples and masterpieces in the arts. 
Later, a change of meaning occurred in the Age of Enlightenment; technology was used as a science of knowledge, which is today's accepted meaning. Technique is the major ally of knowledge and science in various fields of human activity throughout history, and it is the main purpose of the analysis of changes in society. The development of mechanisation and industrialisation on the one hand, and the progress of science on the other, led to a complete transformation of the universe. The new relationships of everyday urban life in contemporary society through art and visual communication by human activity are technical, under the aspects of space and time, and a significant contribution to the factors of perception of the individual and the evolution of his thinking ability, cognition, and aesthetics experience. In the same way that the work of art is consecrated in aesthetics as peinture, poetry, and music, so is the architecture as well as design, i.e., the work of art and the status of aesthetic values presently.

In the early 1919 s, a movement was established with the concept of a "machine aesthetics" that conceptually followed the "technical aesthetics" of Russian constructivists. Such aesthetic-social theories by the Russian constructivists emerged to meet the expectations of a significant part of the population sympathetic to socialist ideals. They adopted as basic principles the production of materials that had greater functionality and technique, thus promoting a more technical purpose than style. It was the most significant characteristic for this creative practice, a kind of "Russian Bauhaus" called Wchutemas, the Russian State Art and Technical School (Bürdek, 2006).

With the movements Arts and Crafts and De Stijl, the rationalization of the design was conceptualized with an aesthetic of reduction that was marked in the Bauhaus in Weimar, Germany. With these movements, one of the most important tasks is the asymmetrical balance of elements configured to new methods in the architectural design process and the rationalisation conceptualising an aesthetic of the reduction that was marked in Weimar. This marked the birth of Bauhaus, which was founded in 1919 by Walter Gropius; it was an art school focused on the interests of industrial development and social needs, paying attention to the functional and technical aspects.

The basis of the aesthetic and social theory of Bauhaus was characterised by compositions and creations in the relationship between art, technology, and industry, exerting influence in the early twentieth century, especially with the advent of design. From 1919 to 1920, from the housing culture and with the social principle of consolidating art to the people, Bauhaus influenced the way of life in society. Additionally, after 1933, the most significant designers 
of Bauhaus left Germany for the United States, influencing a new mainstream style called the International Style and proposing a worldwide trend of the creation and functional realisation of mass culture. From the American perspective, it was a pragmatic form of social development. The designers and architects Frank Lloyd Wright and Le Corbusier are the most prominent names of this style. They stand out because, over time, they became a reference for modernity along with Niemeyer's works. Niemeyer is one of the representative architects in modern architecture. ${ }^{1}$ He became one of Brazil's most significant and internationally recognised architects, including his collaboration with Le Corbusier on the United Nations headquarters and invitations to teach at Yale University and the Harvard Graduate School of Design.

\section{OSCAR NIEMEYER'S CURVE OF TIME}

As a meaningful journey in the history of civilisation and social life, and concerning technological change, the evolution process meets the goals of individuals for their development in large cities. Transformations are considered the main characteristics of urban visual culture as representations of worldviews by characteristics and needs, which vary according to culture, society, and economy.

Evolution leads us mainly to urban development, the increase of the urban population, and the evolution of architecture. The growth of cities requires that projects solve the problems of overpopulation, visual communication, and signaling. The proposals to establish different techniques for urban development are the result of the late twentieth century. The growth of the city has been a phenomenon since the dawn of civilisation. So, time is tied to the ability of the development of projects, the technique for solutions that can be settled in line with the provisions of the growth of urban centres. The relationship of space with the transformation of the city is a great challenge.

The process of change in the configuration of cities implies a means of control in both the growth of the population, as well as the decentralisation of metropolitan areas. We highlight solutions encountered by certain cities that followed the ideas still medieval, but in a new form suited to the contemporary circumstances. A good example of this is the city of Brasília, with its urbanisation project developed by Lúcio Costa, designed mainly by Oscar Niemeyer, and opened on April 21, 1960. The city was designed like an airpline from the sky in a project called Pilot Plan (Plano Piloto). The city of Brasília was designed and only later became the seat of the three governmental powers: the Legislative, 


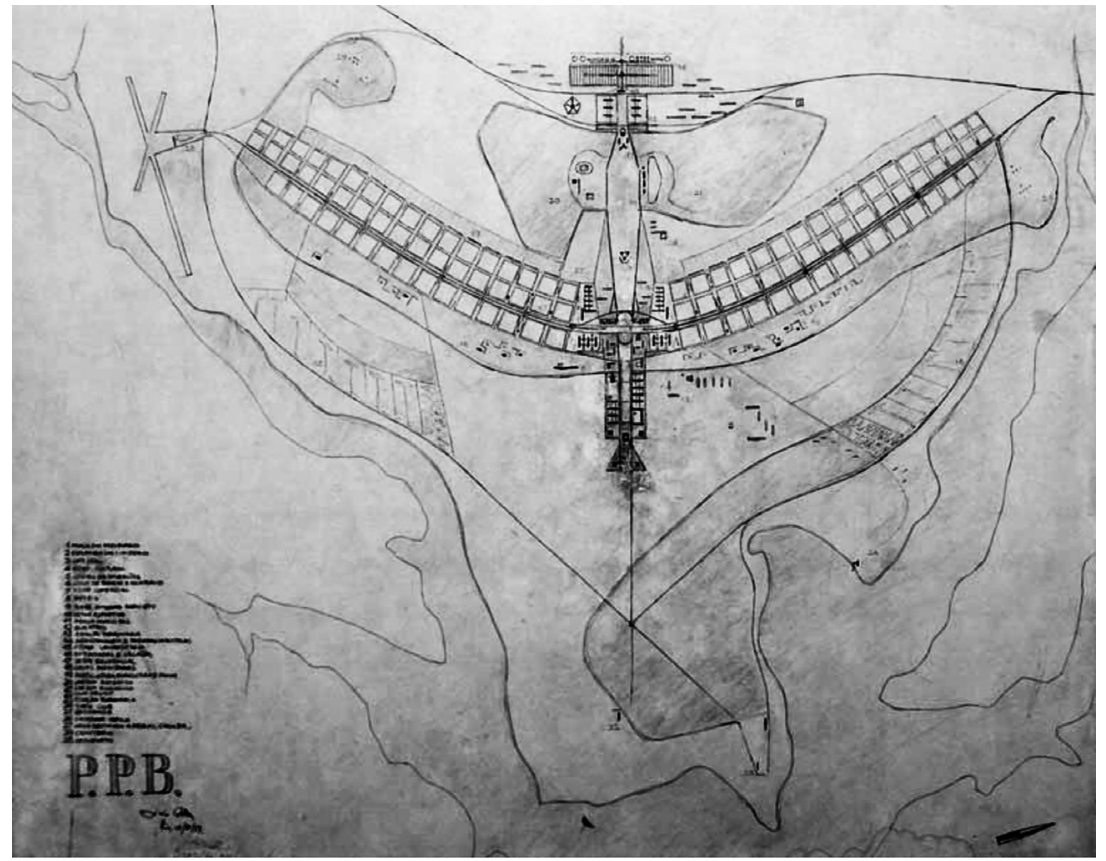

Fig. 1. Sketch indicated by Lúcio Costa in the competition to choose the project, Pilot Plan (Plano Piloto), Brasilia. http://doc.brazilia.jor.br/plano-piloto-Brasilia/plano-Lucio-Costa.shtml.
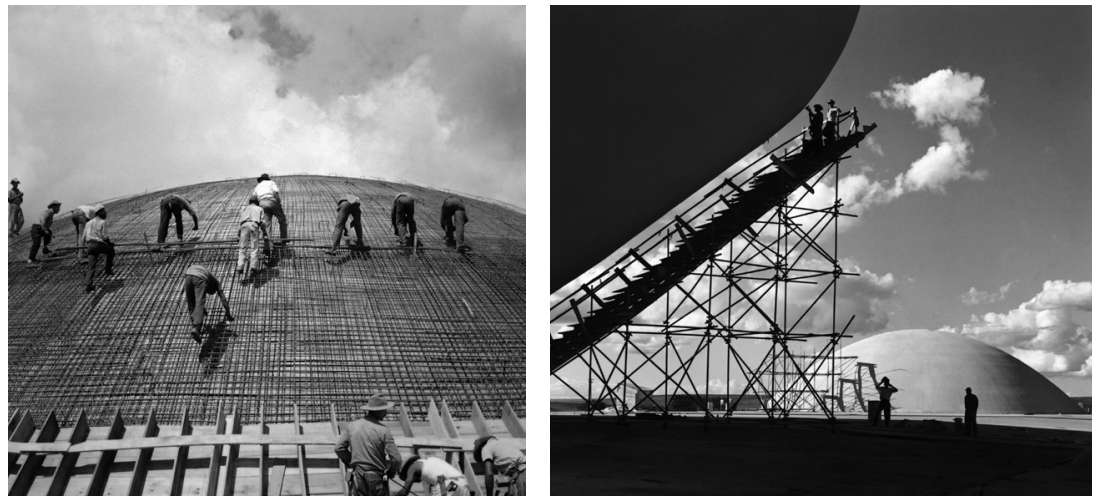

Fig. 2-3. National Congress, Brasília, The Construction of Brasilia, photos by Marcel Gautherot. https://www.archdaily.com/303639/the-construction-of-brasilia-photos-by-marcel-gautherot/. 
the Executive, and the Judiciary (Praça dos Três Poderes/the Three Powers Square). The transformation of the town is more characterised by linear time for the development of society. Ideas allied only to space do not correspond to the results expected from the development of a continually growing city and its transformation and evolution. This transformation took place during industrial development in Brazil under President Juscelino Kubitschek.(Fig. 1, 2, 3)

Sigfried Giedion presented in his work Space, Time And Architecture: The Growth of a New Tradition ${ }^{2}$ an analysis to understand the formations of cities changing. It was an effort to clarify or detail the concepts of growth in a town and transformations regarding the project and creativity for adaptations. We can see from this work that there were impossible ideas to solve the problems of organisation in a constantly changing city, which are those of the destruction of the town and then rebuilding a new one, as Wright wanted. Destruction of the city would be possible only due to a natural disaster. According to Giedion, the conception of space does not occur so isolated and autonomous, but by the organisation of forms in space. In all periods of the history of civilisation, the condition for projection is the perception of time and space concerning the volumes arranged in the internal and external spaces, or that of the interrelation between them. For instance, the spaces of great civilizations like the pyramids of Giza in Egypt or the temples of Athens in Greece - have the volumes arranged in the internal and external areas. What best describes this volume relationship in space was the unlimited extent that this civilisation was planning for space. The meaning of architectural form and the relationship between the internal and external space is of great importance to the spacetime concept when we observe that the sense of tradition works in large spaces with architectural projects of coverage following the shape of the vault.

Also, we can illustrate the predominant characteristics of creativity using the same essential elements, relative to space, placing them in their time, where the symbolic aspects represent tradition but in innovative ways, like the creativity of Niemeyer in the realisation of the National Congress in Brasília, Brazil. Take the speech of the architect: 'And so, by adopting the dome - the dome that the Egyptians used, and Roman multiplied - for the National Congress building.'For Niemeyer, creativity was in the plastic intervention, the modification, seeking as the architect says "to make it lighter". The architecture of the National Congress was carried out with the essential elements, which are the two plenary buildings where the Brazilian government makes decisions. So it was the architect's criteria for its creation 'to highlight them, was our plastic objective, placing them in a monumental terrace where their forms are distinguished as the true symbols of the legislative power'. ${ }^{3}$ (Fig. 4-6) 

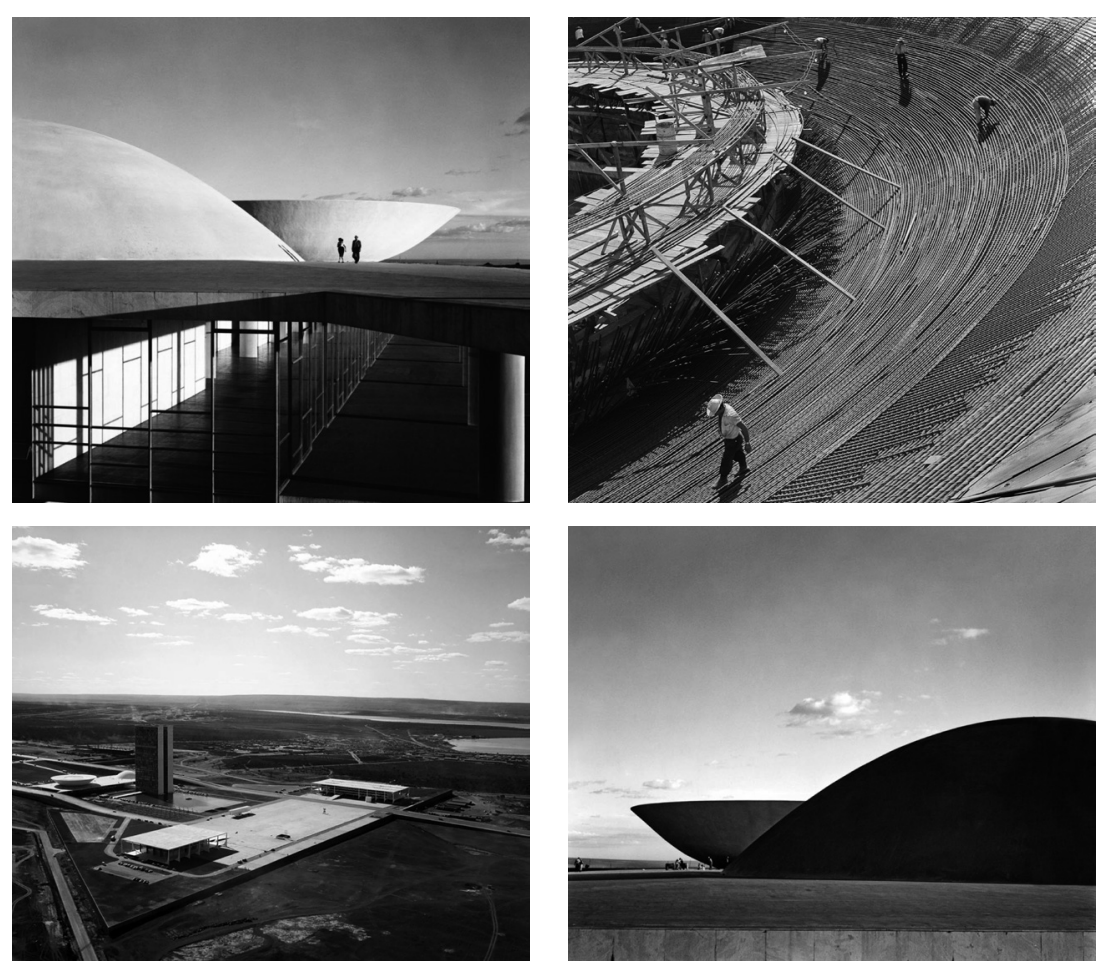

Fig. 4-7. National Congress, Brasília, The Construction of Brasilia, photos by Marcel Gautherot. https://www.archdaily.com/303639/the-construction-of-brasilia-photos-by-marcel-gautherot/.

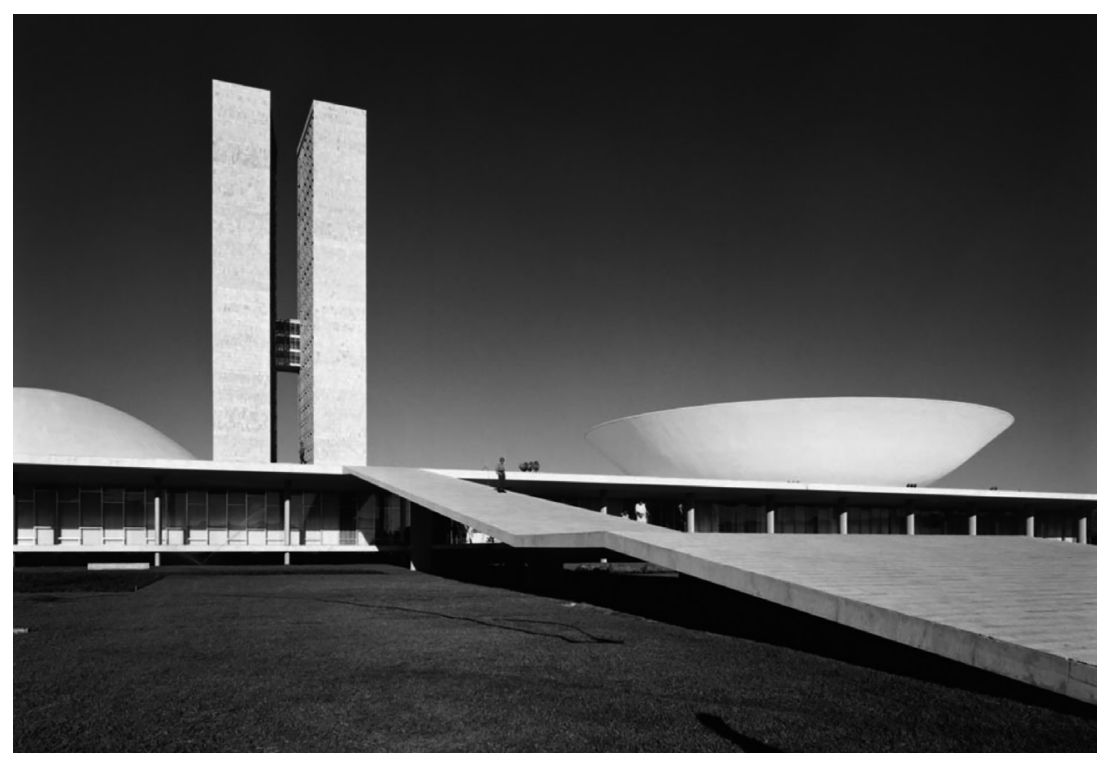

Fig. 8. National Congress, opened on April 21, 1960. Photo by Marcel Gautherot.

https://www.archdaily.com/303639/the-construction-of-brasilia-photos-by-marcel-gautherot/. 
Projects that allow the most massive dome to be in the centre and the lowest points, whether concave or convex, are perceived as an image. This image displays plenty of power, as it was for the Baroque period displaying an impressive aspect by the symmetry of architecture, suggesting optical illusions, and especially a perspective through paintings and frescoes. But over time, perception transforms the same essential elements into new configurations, expressing their values, which are also "absolute" according to their time and space, like Niemeyer by modernity when the values imagined by a nation are translated. As we can see from Giedion's studies, shapes, surfaces, and planes define not only the interior space but also the limits of their dimensions, forming distinct volumes in an open space and interpretation, giving meaning to the design of contemporary architectural space. All questions are part of the world's cultures regarding the past and innovation. Thus, the real world dimension of performance and space in relation to historical brands is the result of technological and social evolution. During the twentieth century, many researchers studied the impact of innovations as essential and necessary in technical cultures, policies, and materials of everyday life.

However, the current consumer society - urban life, for sociologist Edgar Morin is defined by the idea of the relationship between past, present, and future. But in such a way that it causes society to ask: Where will this path lead us? What does the current crisis mean? What is the value of old ideologies? In the face of twentieth-century interests: inventions, innovations, creations, techniques, cultures, and ideologies increased substantially, change evolution or revolutionise the principles of development. Thus, we see sense in Morin's thinking of this subject's analysis in innovation and creation in the form of images, these configurations being the exception to the rule - in a certain way, contemporary art. A feature that reinforces a trend in visual arts and that, in its relation to daily life through exhibitions and also through its interventions, interferes in the urbanisation of large cities. Therefore, consecrated spaces, classified as historical monuments by UNESCO, remain as heritage. However, those who seek innovation by modernity, beginning with the Liberty style in England (1834-1896), by the humanisation of the urban space through art, like William Morris, who wanted unity between architecture, painting, sculpture, and the decorative arts as a global artwork is a reference. Modern architecture, using new materials, gives thanks to new technologies, the result of the industrial revolution, which employed concrete, glass and iron frames. Innovation sets in, and the twentieth century establishes a new image and aesthetic theories. Thus, the functionality mixes industry with the daily life of the metropolis from this conviction: "the form follows the function". Then, by combining public space 
and power, by the word "form", we can understand why "configuration" will be the function, in addition to the image of innovation that will play a strategic role.

Consequently, all contemporary values seek in their configurations the image that could characterise values. The question is: What is the "real" or illusion in each of these achievements in their time and their social reality? Regarding the contrast of many accomplishments that coexist with the works of earlier times, the analysis is more complex, or even when it comes to urban planning. As an example, the simplest solution is the absurdity of destruction of cities for the design of new spaces, as desired by Wright. But, for the innovative realisation, others were lucky to find almost a destruction - an evacuated space, ready for the construction of a planned city, as is the case of Brasilia, by the architects Costa and Niemeyer. An achievement that, additionally, was favoured by the political and social moment - Brazil's development process. Given the vast region, other reasons have supported innovative works in the current space as a function of time - contemporaneity.

The most significant aspect of Niemeyer's architecture is Le Corbusier's influence with the use of concrete. Basically, at the beginning of concrete usage for a new architecture, two conditions are necessary: first, a tectonic expression of load-bearing walls. The second is that architects and built industries are used, within limits, to reach more solutions in their constructions with less work. That is a cheap method to build, allowing mass production. Reinforced concrete determined the principles of a new architecture. There are five points. First, the pilotis: supporting the horizontal slabs and elevating the building from the earth, in contrast with the ancient Greek temples. By applying pilotis, reinforced concrete enables more spacial and analogous floors. In this way, the pilotis are, for the new architecture, an achievement of perfection and democratic space. Second is the roof garden: itself one of modernism's object-types. By freeing the columnar structure from the interior partitions that enclose the program, Le Corbusier created the free plan. The free plan was also known as the paralysed plan, or plan of rooms with little difference from one another, especially without the support of a wall; due to the pilotis technical achievements, the walls did not support much of the weight of the overlying parts of a building or other structure. The ribbon window, for example, is an interior window that enables a pass-through from one room to another by cutting an opening in a wall, which is not load-bearing or supporting the roof. Next is the free façade - there are open doors or windows similar to the ribbon window system. However, the exterior walls are now opened up to allow for more natural light and a view of the nature. 
This point of a new architecture is one of the most elevated positions of Le Corbusier's interest related to an aesthetic experience. Therefore, Niemeyer's design is possible due to the mastery of technology, in these circumstances of modernity, rather than being a mechanism by which mass pressure is applied against the mass culture; it is a mechanism for taming the representatives of mass production. In this way, Le Corbusier made architecture powerful and more accessible to control through technology, and Niemeyer improved them with his remarkable architecture "the curves of time". An architect is a creator.

By analysing the configurations of human social life throughout the evolutionary history of humanity, we realise that, in the nineteenth century, the separate existence of an Ecole des Beaux-Arts and an Ecole Polytechnique in Paris pointed to a schism between architecture and construction, regarding Giedion (1941). Hence, I find that "technology transfer" has always been an interaction between nature and culture for all possible realizations of human civilization throughout time - Zeitgeist. This schism became evident between architecture and technology when, as stated by Giedion, "the exhibition became the trial ground for new methods. In all the great international exhibitions - from the first at Crystal Palace, London, in 1851 to the last at the end of the century constructors attempted tasks that had never been faced before." In these ways, for me, more complex environmental aesthetics can be understood through inventions and artifices in the form of new materials composition. The most significant materials employed are stone, iron, and glass at the beginning of the nineteenth century, for example at Crystal Palace in 1851.

The development of industry in all its branches was accelerated by these exhibitions, in which every sphere of human activity was represented: the implements, methods, and products of mines, mills, machine, shops, and farms were on display, together with work in the fine and the applied arts. ${ }^{4}$

But since Bauhaus, concrete is the most significant material employed - from Bauhaus to the present with Niemeyer's architecture, which was built following the concrete technologies. Also, through aesthetic practice, Niemeyer's architecture can integrate art with techniques and industry for modern architecture, expressed through the outline of the curve, the precision of the pieces, and the clarity of the assembly.

In this respect, for the schism between architecture and technology, two aspects of cultural transformation are important: technique - in which the term 'art' is included - and science as technologies. Aside from the attraction of 


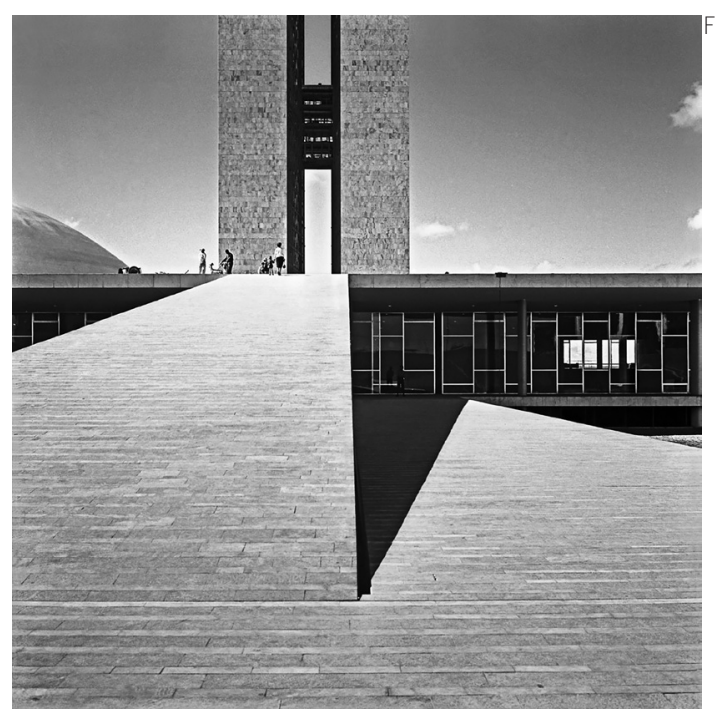

ig. 9. Palace of the National Congress, Brasília. Photo by Marcel Gautherot. https:// artblart.com/2015/06/21/ exhibition-modernitesphotographie-bresilienne1940-1964-at-the-fondationcalouste-gulbenkian-paris/.

Fig. 10.Itamaraty Palace, Brasília. Photo by Marcel Gautherot. https://www.momdaily.com/ gallery/old-brasilia-gallery/.

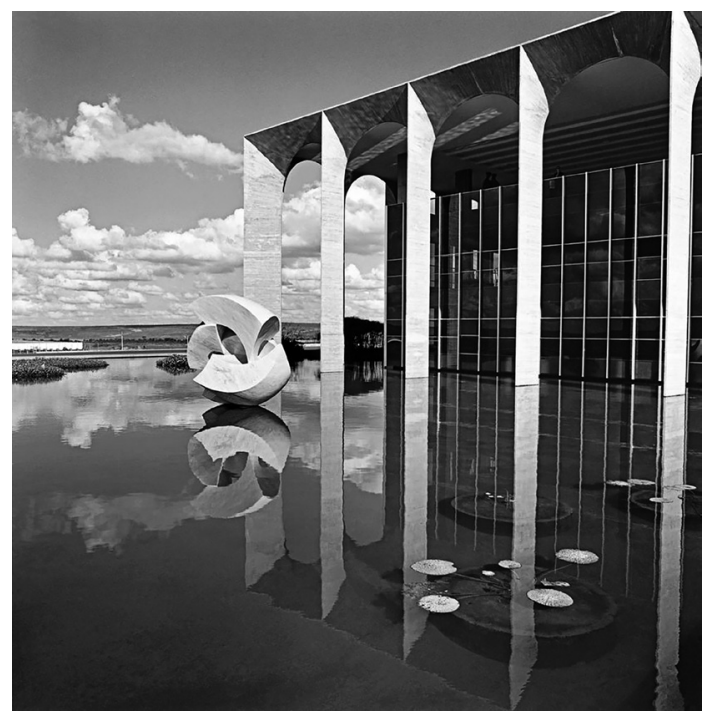


Niemeyer's composition with the curve, which was always emphasised in the architectural process and modern development, the technical aspects of the curves configurations is highlighted as well as in the world and Weltanschauung by changing as a result of scientific and technological advances. By analysing the configurations of the Niemeyer's architecture presented, this proposal is divided into a consideration of two different perspectives. The first is a building highlighted from the landscape. The second, however, reveals a configuration of a structure in the environment, highlighting the curve forms. Comparatively, the two points of view indicate that the buildings have been contrasted with the environment. But the second one distinguishes more than the first, with its curve form in contrast with the environment, while in the other one, we have a similar colour predominance. In this respect, two aspects of configuration as a form are important: element and space.

Overall, the general characteristic to observe in these architectural projects are the geometrical form of the curve. These forms, which always emphasised the outlining of the curve, have to be described through our perception. It should be a singular experience, with the different capacity of understanding the relationship of the forms, or not, from each of us. Therefore, we start a process of aesthetic judgment - a judgment with cultural influence and knowledge, that, even though, can be singular and also universal. 

$\underline{\mathrm{html}}$.

Sigfried Giedion, Space, Time And Architecture: The Growth Of A New Tradition (Cambridge: Harvard University Press, 1982). Oscar Niemeyer, The Curves of Time: The Memoirs of Oscar Niemeyer (London: Phaidon, 2000). Harvard University Press, 1982), 178. 
Eichhorn, Ulrike. Oscar Niemeyer in Berlin. Berlin: Edition Eichhorn, 2013.

Kurianowicz, Tomasz. Bauhaus, Stadtführung durchs Hansaviertel. Berlin: Tagesspiegel, 2012. Available at: http://www.tagesspiegel.de/kultur/bauhaus-stadtfuehrung-durchs-hansaviertel/64 $\underline{54176 . h t m l}$.

Giedion, Sigfried. Space, Time And Architecture: The Growth Of A New Tradition. Cambridge: Harvard University Press, 1982.

Gropius, Walter. Staatliches Bauhaus in Weimar 1919-1923 (Hrsg. vom Staatlichen Bauhaus, Weimar und Karl Nierendorf in Köln). Weimar und München: Bauhaus Verlag,1923.

Hegel, G .W. F. Vorlesungen über die Ästhetik. Frankfurt a. M.: Suhrkamp, 1986.

Kant, Immanuel. Kritik der reinen Vernunft. Stuttgart: Reclam, 2006.

Kant, Immanuel. Kritik der praktischen Vernunft. Stuttgart: Reclam, 2008.

Niemeyer, Oscar. The Curves of Time: The Memoirs of Oscar Niemeyer. London: Phaidon, 2000.

Pelzing, Ernst. Architekturgeschichte. Berlin: Spiegel Online, 2010. Available at: http://www. spiegel.de/einestages/architekturgeschichte-a-948648.html.

Picon, Antoine. "Construction History: Between Technological and Cultural History." Construction History, vol. 21 (2006): 5-19.

Thöner, Wolfgang and Ute Ackermann. Das Bauhaus lebt. Leipzig: Henschel, 2009.

Siebenbrodt, Michael. Kunstsammlungen zu Weimar. Weimar: Bauhaus-Museum, 2006.

Siebenbrodt, Michael. Bauhaus Weimar, Entwürfe für die Zukunft. Ostfildern: Hatje Cantz, 2000.

Warnke, Martin. Das Kunstwerk zwischen Wissenschaft und Weltanschauung. Gütersloh: Bertelsmann-Kunstverlag, 1970. 


\section{ESTETIKA ODRŽIVOSTI: ARHITEKTURA KAPSULE U GRADU I U PRIRODI Peter Šenk}

Arhitektura najmanjih mesta za stanovanje je u poslednje vreme izuzetno popularna tema. Kada su najmanja mesta za stanovanje kompaktna, dobro opremljena, povezana na mrežu, strukturno, funkcionalno i vizuelno prepoznata kao jedna stvar, privremena i pokretna ili prenosiva, mogu se označiti kao arhitektura kapsule. Budući da su po svojoj prirodi privremena, ova najmanja mesta za stanovanje, skloništa, redizajnirane kontejnerske jedinice, posebne tehnološke konstrukcije, paraziti i druge manifestacije koncepta kapsula obuhvataju logiku tehnoloških objekata s izrazitim arhitektonskim izrazom. To je, istovremeno, manifestacija pravila održivog dizajna, održive arhitekture i održivosti uopšte. U ovom kontekstu slučaj najmanjih mesta za stanovanje pokazuje svoju razliku u odnosu na druge održive arhitektonske pristupe i estetike. Podredjuje uopšteno održive pristupe sa izraženim značajem lokaliteta unutar globalnih sila, obično se oslanjajući na kontekst - lokaciju, lokalnu kulturu i karakteristike životne sredine itd. Estetski režim trenutnih, promenljivih, kontekstualnih i autonomnih arhitektonskih struktura se može posmatrati kao estetika drugosti, koja ih povezuje sa nasledjem egzistencijalnih eksperimenata modernog pokreta, novim brutalizmom, radikalnim eksperimentima 1960-ih i drugim avangardnim i neoavangardnim praksama dvadesetog veka, ali čvrsto postavljenim u kontekstu individualizovane, neodredjene, raspršene i dvosmislene savremenosti.

KLJUČNE REČI: ESTETIKA PROMENE, KAPSULE, NAJMANJA MESTA ZA STANOVANJE, MINIMALAN TRAG, DRUGOST, ESTETIKA ODRŽIVOSTI

\section{ESTETIKA I KULTUROLOŠKI ASPEKTI BAUHAUSA: \\ KA NOVOJ KONCEPCIJI}

\section{Christiane Wagner}

Ovaj članak pokriva nove mogućnosti Bauhaus pogleda na svet: stvaranje novih oblika za prikazivanje ljudskih ideala kroz fokus na estetiku i tehnologiju, u kombinaciji sa Nimajerovim (Niemeyer) uticajem na arhitekturu i dizajn. Novi stilovi i oblici nastali su kao izdanci Bauhausa, prenoseći vrednosti svake kulture kroz izgradnju kolektivne „slike“ sveta. Bauhaus današnjice izražava industriju kulture, dijalektički razmatrajući inovaciju i primenjenu umetnost kao put od modernog dizajna industrijske revolucije do „eko dizajna“. U tom smislu, Bauhaus je još uvek značajan po svojoj ulozi, povezujući umetnost, tehnologiju i industriju. Inovacija kao dinamično odredjivanje trenutka, prisutna u svim epohama, se shvata kao moćna sila za održavanje tradicije. Pored hronološkog zapisa o uticaju Bauhausa, razmatraju se i značajni Nimajerovi projekti. Na kraju su prikazane dve perspektive ,raskola“ izmedju arhitekture i tehnologije. Prva perspektiva se odnosi na ljudsku sposobnost stvaranja modela u arhitektonskoj praksi za usvajanje kao konfiguraciju prostora. Druga se odnosi na evoluciju tehnologija koje vode do toga da zamišljeno postaje stvarnost kroz vreme, kako je to opisao Hegel (1823).

KLJUČNE REČI: IZRADA PO MERI, TEHNOLOŠKI RAZVOJ, PROSTOR-VREME, NOVI OBLICI

\section{KLASIČNA ARHITEKTURA U OKVIRU KANTOVSKE ESTETIKE: IZMEĐU LIOTARA I RANSIJERA}

\section{Helen Tatla}

Potencijal koji je svojstven klasičnoj arhitekturi da predstavlja glavni arhitektonski izraz zapadne kulture budući da je grčka antika nastala zbog svog dualnog karaktera: iako izvire iz iskonskog jedinstva stvari izraženih mitom i religijom u arhaičnim vremenima, ona dobija svoj završni oblik u petom veku p. n. e., kao simbol demokratije i harmonične artikulacije sveta na osnovu filozofskog mišljenja. 